\title{
A Systematic Mapping Study on Customer Loyalty and Brand Management
}

\author{
Andrea Moretta Tartaglione, Ylenia Cavacece *, Giuseppe Russo and Giuseppe Granata \\ Department of Economics and Law, University of Cassino and Southern Lazio, 03043 Cassino, Italy; \\ a.moretta@unicas.it (A.M.T.); giuseppe.russo@unicas.it (G.R.); g.granata@unicas.it (G.G.) \\ * Correspondence: ylenia.cavacece@unicas.it
}

Received: 10 November 2018; Accepted: 4 January 2019; Published: 11 January 2019

\begin{abstract}
Customer loyalty is a topic of great interest for marketing scholars due to its importance in gaining sustainable competitive advantages and financial outcomes. Literature is prolific of works regarding customer loyalty and brand management. In order to improve the quantity and quality of research publications, research themes mapping of published studies is required. The aim of this paper is to provide scholars with a systematization and mapping of the contributions on this topic to develop an effective research road map for future research. A bibliometric analysis and a mapping study have been conducted on 337 publications on customer loyalty and brand management from 2000 to 2018. The results present the most cited works on the topic, an evaluation map showing the most frequent and cited words and six clusters of words based on their co-occurrence. From the analysis of the clusters, the most relevant research findings, trends, and issues emerge, suggesting interesting theoretical and practical implications.
\end{abstract}

Keywords: customer loyalty; brand; satisfaction; commitment; trust; engagement; bibliometric analysis; mapping study

\section{Introduction}

Customer loyalty is one of the most debated topics in marketing literature of last decades. The great interest in customer loyalty can be attributed to its importance in achieving sustainable competitive advantages and financial outcomes (Grönroos 2009). Customer loyalty refers to positive attitudes of customers toward a company or brand that result in repeated repurchasing behaviors and in a lower customer sensitivity to the price and the offerings of competitors (Anderson and Srinivasan 2003). Loyal customers are more profitable than a new one, since they spend more with the firm and have lower servicing costs (Richard and Zhang 2012). Hence, managing and enhancing customer loyalty becomes a strategic imperative for firms.

Brand acquires great importance in improving customer loyalty through the effective management of the brand awareness and brand image (Han et al. 2008). The emotional attachment towards a brand creates affective commitment that encourages consumers to constantly rely on a specific brand's offering (Gustafsson et al. 2005; Lee et al. 2007), repurchase the same brand, spread good words, and not visit competitor's stores (Han et al. 2018). These behaviors ultimately result in customer loyalty (Evanschitzky et al. 2006; Fullerton 2005; Iglesias et al. 2011; Mattila 2001).

The interest in customer loyalty has resulted in a large number of contributions on this topic. Literature shows interesting advancements in its understanding and conceptualization. However, to date, further efforts are required of scholars (Nguyen et al. 2018; Shahid Iqbal et al. 2018; Sitorus and Yustisia 2018). The reason is that customer loyalty is a complex and multifaceted concept involving dynamic interactions and exchanges (Dick and Basu 1994). It is a multidimensional construct and some difficulties emerge in identifying its dimensions and operationalize them. First of all, customer 
loyalty can be defined as a combination of attitudinal and behavioral dimensions that create difficulties in analyzing it (Richard and Zhang 2012). Second, a large amount of research has been devoted to investigating its antecedents and consequences (Han et al. 2008; Pan et al. 2012) because loyalty is related to other complex variables like consumer involvement, trust, satisfaction, commitment, and engagement (Ball et al. 2004; Huang et al. 2006; Hajli et al. 2017). Moreover, in last years, the evolution of consumers and the development of social media have profoundly changed the consumers' behaviors and the way that they interact with other consumers and with the firm itself (Dolan et al. 2016; Gensler et al. 2013; Pentina et al. 2013).

For scholars, therefore, it is not easy to identify the directions to which address their efforts aimed at contributing to the advancement of the research on this topic. This paper aims to provide an overview of the research findings and trends by mapping the research field in clusters able to guide the researcher to the most influential works, results, and issues that need more insights.

With this end, this paper offers a bibliometric analysis and a mapping study of the works on customer loyalty and brand management.

Traditionally, researchers have analyzed earlier findings using two methods: the qualitative approach of a structured literature review and the quantitative approach of meta-analysis (Schmidt 2008). In last years, thanks to the introduction of online databases with citation data (e.g., Web Of Science) and the proliferation of software for conducting bibliometric analyses (e.g., SciMAT and BibExcel), bibliometric methods have spread.

Bibliometric methods use a quantitative approach for the description, evaluation, and monitoring of published research. These methods, by using a systematic, transparent, and reproducible review process, allow the overcoming of the limits of narrative literature reviews, which often lack rigor and are exposed to bias by the researcher (Tranfield et al. 2003).

As highlighted by Zupic and Čater (2015), bibliometric methods have been widely used to map the fields of strategic management since 1999. In the field of customer loyalty, Siemieniako (2018) provides a bibliometric analysis of scientific works published in the Scopus database in the period from 2003 to 2017; the analysis is focused only on the customer loyalty in the business-to-business context. With regard to the topic of brand management, some bibliometric analyses have been conducted, particularly on the consumer brand relationships (Fetscherin and Heinrich 2015), on brand personality (Llanos-Herrera and Merigo 2018; Radler 2018), and on corporate branding (Fetscherin and Usunier 2012). This work contributes to the previous knowledge by analyzing customer loyalty for both the B2B and B2C contexts, with a focus on the relationships between customer loyalty and brand management.

Among the different bibliometric methods, this paper adopts the science mapping, which allow for mapping the cognitive structure and evolution of scientific fields and disciplines (Noyons et al. 1999) producing a spatial representation of them (Calero Medina and Leeuwen 2012; Small 1999). Based on the citation index, the most important papers on customer loyalty and brand management have been identified and analyzed to display the structural and dynamic aspects of scientific research (Börner et al. 2003; Morris and Van der Veer Martens 2008). In a second phase, the different works have been clustered on the basis of the words co-occurrence and each cluster has been analyzed to facilitate the identification of the relationships between each dimension involved.

This work is organized, as follows: first, the method used is described; second, results are illustrated and then discussed; finally, conclusions, theoretical and practical implications are provided.

\section{Materials and Methods}

This work is based on a bibliometric analysis and mapping study of the contributions about customer loyalty and brand management.

Document information was recovered from the Web of Science's (WOS) SCI-Expanded by Thomson Reuters. This database was chosen because it offers a significant advantage being multidisciplinary and including social sciences literature (Norris and Oppenheim 2007). 
The analysis was carried out by searching for the Topic: (customer loyalty AND brand management), refined by: Web of Science Categories $=($ Business or Management $)$ AND Document Types $=($ Article or Review or Book Chapter $)$, using Indexes $=$ Sci-Expanded, SSCI, A\&HCI, CPCI-S, CPCI-SSH, BKCI-S, BKCI-SSH, ESCI, CCR-Expanded, IC (Waltman 2016). The search was conducted during September 2018 within the Timespan $=2000-2018$ because a substantial presence of works on the subject was detected only starting from 2000 (only four works were found in all the '90s).

Results have been collected in a unique database containing the variables of authors, language, year of publication, type of research, country, keywords, and cited references in each of the publications included in the search.

First, a bibliometric analysis was conducted to identify the total publications by year, the sum of times cited by year, the most cited authors, and productive countries. A top ten of the most cited publications was created. Subsequently, the scientific mapping study was carried out using the software SciMAT, developed by the "SECABA" group from the University of Granada, which allows the construction of scientific maps as well as a better visualization of the evolution within a scientific area (Cobo et al. 2012). SciMAT provides different modules that help the analyst conduct a science mapping workflow: a module that is dedicated to the management of the knowledge base and its entities, a module responsible for conducting the science mapping analysis, and a module to visualize the generated results and maps (Cobo et al. 2012).

To perform the analysis, the following configuration in SciMAT was established: word as the unit of analysis, co-occurrence analysis as the tool to build the networks, equivalence index as the similarity measure to normalize the networks, Jaccard index as the evolution measure, Inclusion index as the overlapping measure, the H-Index to detect the relevance, and the simple centers algorithm as the clustering algorithm to detect the clusters (Castillo-Vergara et al. 2018). The analysis provides an evaluation map for the topic "customer loyalty and brand management" with the most occurring words and their relevance in the publications analyzed. The relevance of the words was established on the basis of three measures: documents count, H-Index, and sum citations. For each relevant word of the analysis, a cluster of the related words was created, graphically showing the relevance of each word in the cluster and the links between each one.

\section{Results}

\subsection{Bibliometric Analysis}

The search on Web of Science yielded 337 publications on customer loyalty and brand management. Publications started from 2000 and grew exponentially, reaching a pick in 2017. Because the search was conducted in September 2018, data related to the year 2018 are not complete but looking at the trend, it is assumed a confirmation of growth also for this year (Figure 1). Citations of works about customer loyalty and brand management date back to 2002 and then grew over the years, showing a constant growth rate (Figure 1).

Total Publications by Year

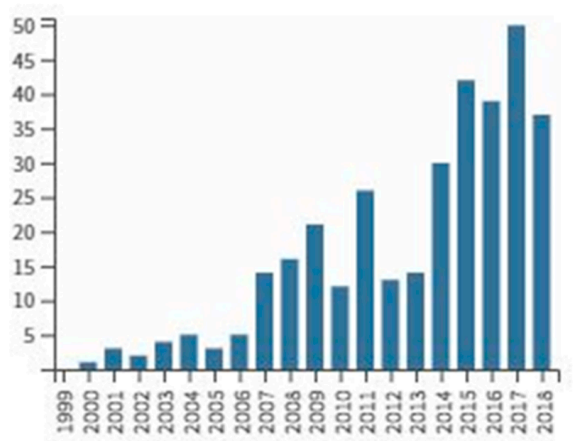

Sum of Times Cited by Year

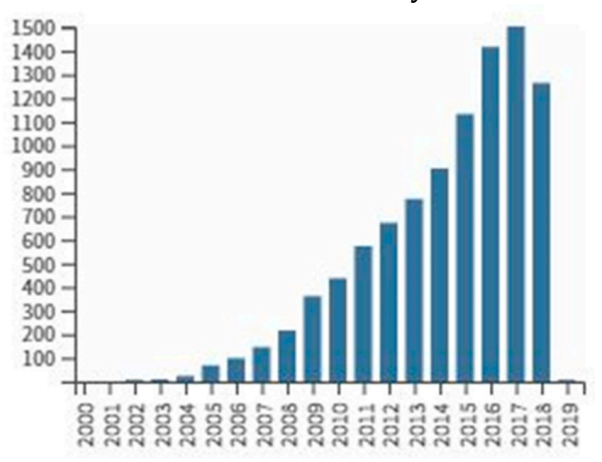

Figure 1. Publications and citations distribution by year. 
Among the most productive authors, we find Heiner Evanschitzky, Sunil Gupta, and Peter C. Verhoef and most of the works have been published in the United States (Figure 2).

\section{Most Productive Authors}

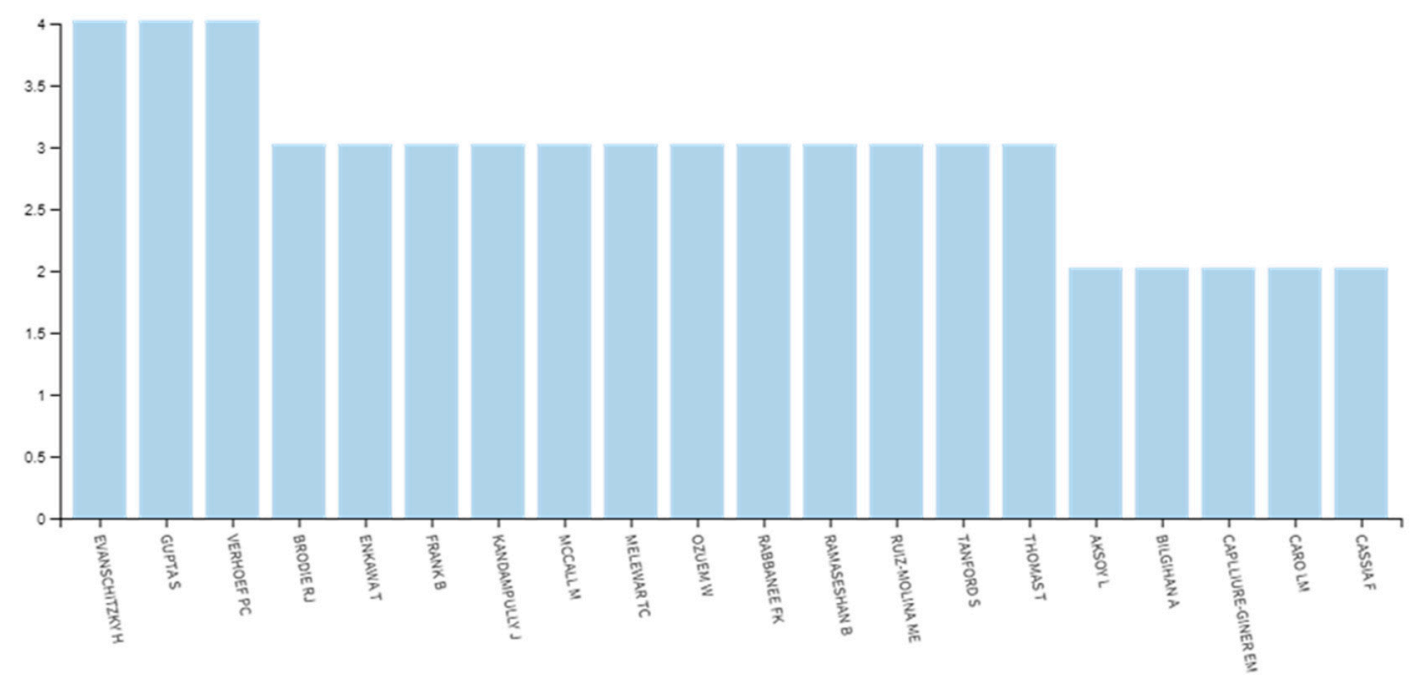

Most Productive Countries

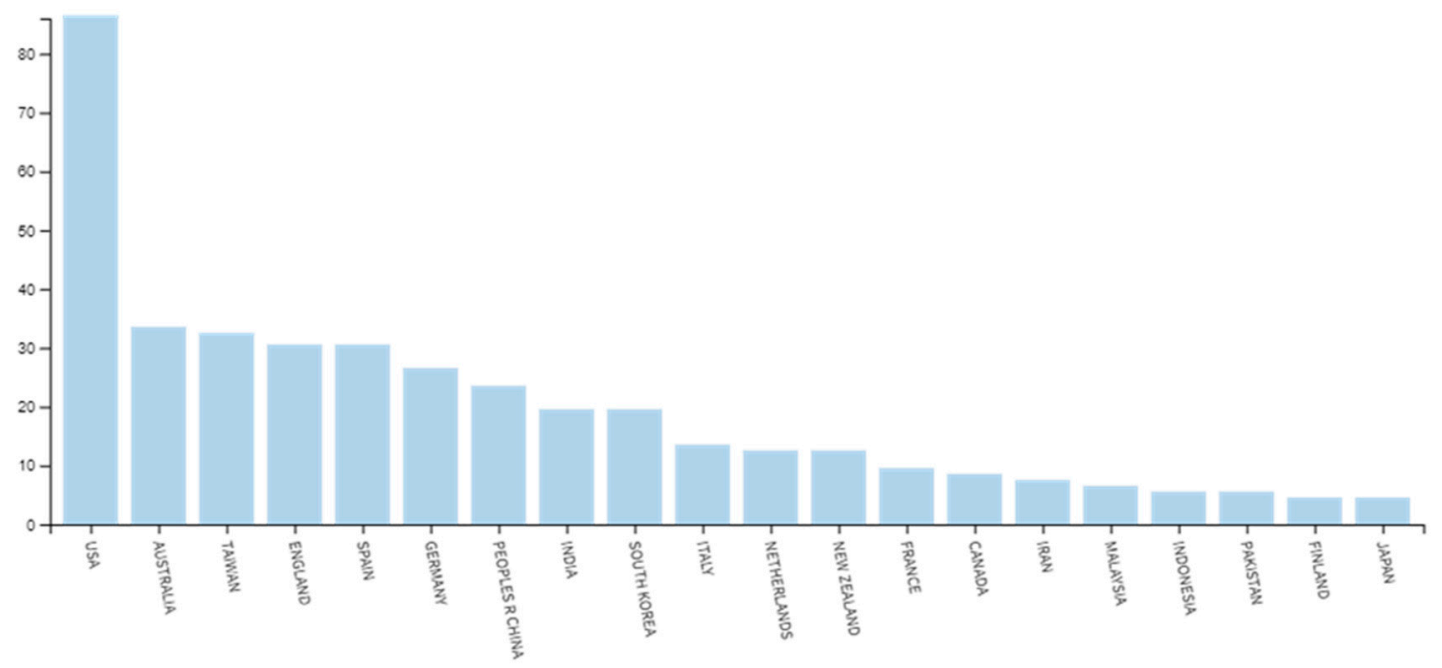

Figure 2. Most productive Authors and Countries.

The study of customer loyalty and brand management is transversal to different fields of study in the research areas of management and business, belonging to both the B2C and B2B contexts; the main ones are listed in the Table 1.

Table 1. Fields of study.

\begin{tabular}{cc}
\hline Field of Study & Most Relevant Works \\
\hline Retail & (Chiou et al. 2010; Baltas et al. 2010) \\
e-Commerce & (Jin et al. 2008; Ng 2013; Chen et al. 2009) \\
Social media & (Gamboa and Gonçalves 2014; Van Doorn et al. 2010; Zhang and Luo 2016) \\
Service sector & (Cassia et al. 2017; Han et al. 2008; Caruana 2002) \\
Hospitality \& Tourism & (Chen and Myagmarsuren 2010; Horng et al. 2012; Huang et al. 2006) \\
\hline
\end{tabular}

Table 2 shows a top ten of the most cited works about customer loyalty and brand management. From the analysis of these works, it is possible to identify the most relevant research topics in the literature on customer loyalty. First of all, it should be noted that there is a strong interest from 
the scientific community in the attempts of identification and operationalization of the dimensions of customer loyalty and their links with other variables related to the consumer, like satisfaction and engagement, or to the company, like reputation and brand image. Particularly, the work of McAlexander et al. (2002) tries to conceptualize customer loyalty as integration in a brand community and it received 894 citations since its publication. A great interest is also shown by scholars towards customer engagement behaviors (CEBs), defined as the customers' behavioral manifestation toward a brand or firm, beyond purchase, that results from motivational drivers (Van Doorn et al. 2010). The attention is on the antecedents, impediments, and firm consequences of customer engagement (Verhoef et al. 2010).

Table 2. Top 10 of the most cited works on customer loyalty and brand.

\begin{tabular}{|c|c|c|c|c|}
\hline Authors & $\begin{array}{c}\text { Publication } \\
\text { Year }\end{array}$ & Title & $\begin{array}{c}\text { Total } \\
\text { Citations }\end{array}$ & $\begin{array}{l}\text { Average } \\
\text { per Year }\end{array}$ \\
\hline $\begin{array}{c}\text { McAlexander, J.H.; } \\
\text { Schouten, J.W.; Koenig, H.F. }\end{array}$ & 2002 & Building brand community & 894 & 52.59 \\
\hline $\begin{array}{l}\text { Van Doorn, J.; Lemon, K.N.; } \\
\text { Mittal, V.; Nass, S.; Pick, D.; } \\
\text { Pirner, P.; Verhoef, P.C. }\end{array}$ & 2010 & $\begin{array}{l}\text { Customer Engagement Behavior: Theoretical } \\
\text { Foundations and Research Directions }\end{array}$ & 518 & 57.56 \\
\hline $\begin{array}{l}\text { Ganesh, J.; Arnold, M.J.; } \\
\text { Reynolds, K.E. }\end{array}$ & 2000 & $\begin{array}{l}\text { Understanding the customer base of service } \\
\text { providers: An examination of the differences } \\
\text { between switchers and stayers }\end{array}$ & 429 & 22.58 \\
\hline Rauyruen, P.; Miller, K.E. & 2007 & $\begin{array}{c}\text { Relationship quality as a predictor of B2B } \\
\text { customer loyalty }\end{array}$ & 297 & 24.75 \\
\hline $\begin{array}{l}\text { Johnson, M.D.; Herrmann, } \\
\text { A.; Huber, F. }\end{array}$ & 2006 & The evolution of loyalty intentions & 278 & 21.38 \\
\hline Yi, Y.J.; Jeon, H. & 2003 & $\begin{array}{l}\text { Effects of loyalty programs on value } \\
\text { perception, program loyalty, and brand loyalty }\end{array}$ & 245 & 15.31 \\
\hline $\begin{array}{l}\text { Cooil, B.; Keiningham, T.L.; } \\
\text { Aksoy, L.; Hsu, M. }\end{array}$ & 2007 & $\begin{array}{l}\text { A longitudinal analysis of customer satisfaction } \\
\text { and share of wallet: Investigating the } \\
\text { moderating effect of customer characteristics }\end{array}$ & 243 & 20.25 \\
\hline $\begin{array}{l}\text { Verhoef, P.C.; Reinartz, W.J.; } \\
\text { Krafft, M. }\end{array}$ & 2010 & $\begin{array}{l}\text { Customer Engagement as a New Perspective in } \\
\text { Customer Management }\end{array}$ & 220 & 24.44 \\
\hline Cretu, A.E.; Brodie, R.J. & 2007 & $\begin{array}{l}\text { The influence of brand image and company } \\
\text { reputation where manufacturers market to } \\
\text { small firms: A customer value perspective }\end{array}$ & 220 & 18.33 \\
\hline Yi, Y.J.; La, S. & 2004 & $\begin{array}{l}\text { What influences the relationship between } \\
\text { customer satisfaction and repurchase intention? } \\
\text { Investigating the effects of adjusted } \\
\text { expectations and customer loyalty }\end{array}$ & 210 & 14 \\
\hline
\end{tabular}

In the same way, many authors have found useful for their research the study of Ganesh et al. (2000), which provides insights for a deeper understanding of the customer base in order to target the customer retention and loyalty-building efforts to the right customers. Another study of interest concerns the dimensions of relationship quality that can explain the influence of relationships on customer loyalty in terms of behavioral aspects (purchase intentions) and attitudinal loyalty (Rauyruen and Miller 2007); trust, commitment, satisfaction, and service quality are considered among the most important relationship quality dimensions. From the analysis of the selected publications, it also emerges a great scientific interest about the drivers of customer loyalty intentions toward the brand as variables that mediate the effects of value on intentions (Johnson et al. 2006). Other debated themes are the relationship between customer satisfaction and customer retention as the primary measure of loyalty (Cooil et al. 2007) and the influences of brand image and company reputation on customers' perceptions of quality, customer value, and customer loyalty (Cretu and Brodie 2007).

Finally, other most cited works investigate how loyalty influences the relationship between customer satisfaction and repurchase intention (Yi and La 2004), and how reward schemes of a loyalty 
program influence the perceived value of the program and how value perception of the loyalty program affects customer loyalty (Yi and Jeon 2003).

\subsection{Mapping Study}

From the scientific mapping study, an evaluation map emerged showing six relevant nodes. These nodes represent the most frequent words in the analyzed documents, as well as the most cited and relevant ones that are based on H-Index. As Figure 3 shows, customer satisfaction is the most frequent, relevant, and cited topic in the works on customer loyalty and brand management, followed by consumer trust, brand community, consumer perceptions, consumer behavior, and competitive advantage.

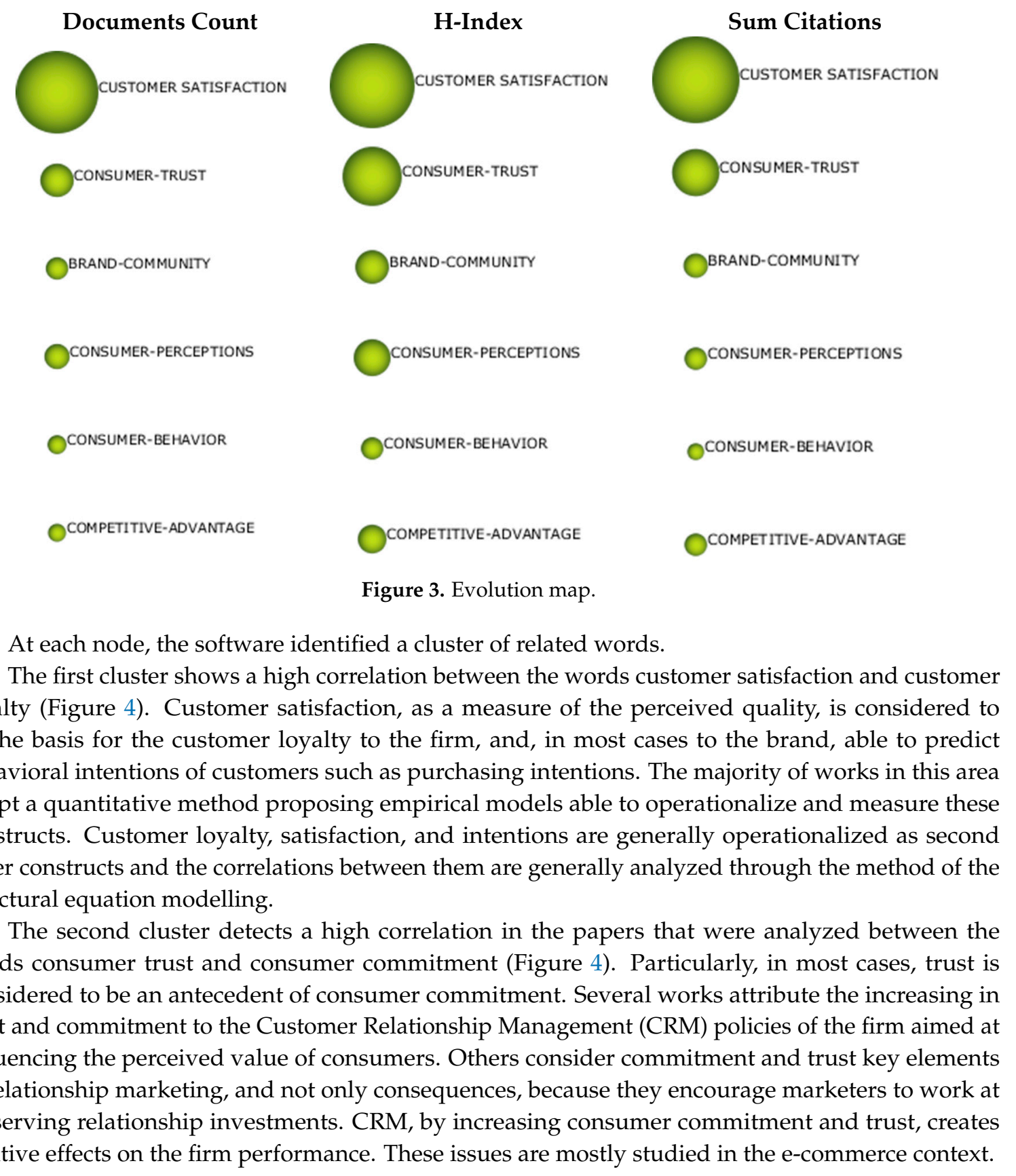




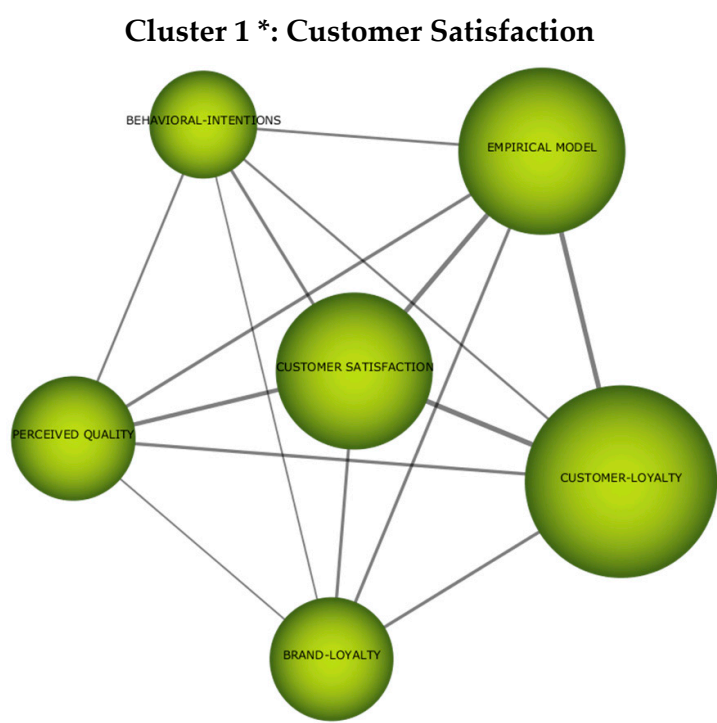

$$
\begin{gathered}
\text { Node } \\
\text { Customer } \\
\text { Satisfaction } \\
\text { Customer-Loyalty } \\
\text { Empirical Model } \\
\text { Perceived Quality } \\
\text { Brand Loyalty } \\
\text { Behavioral Intentions }
\end{gathered}
$$

Most cited work

Evanschitzky and Wunderlich 2006 Kumara and Shah 2004 Cooil et al. 2007 Frank et al. 2014 Yi and Jeon 2003 Forgas-Coll et al. 2014

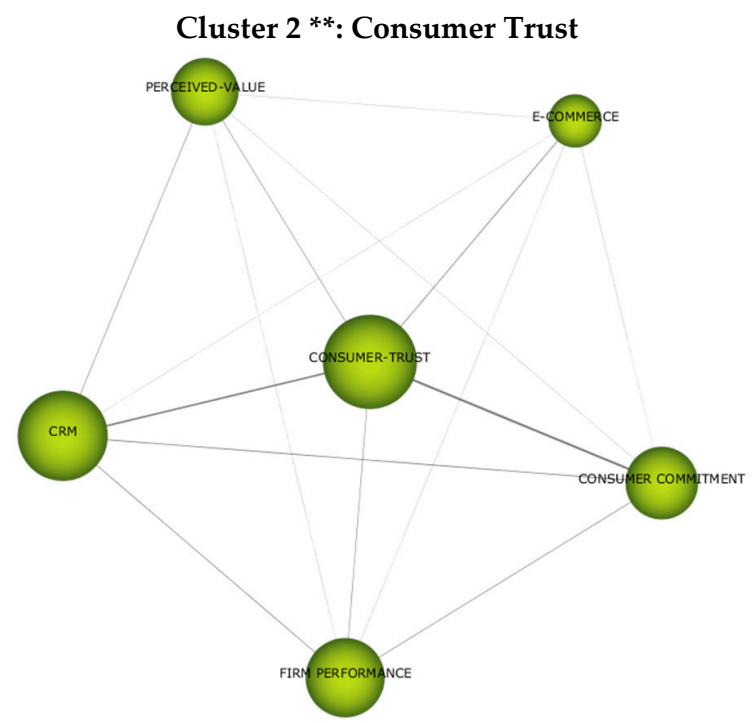

Node

Consumer Trust

CRM

Firm Performance

Consumer Commitment

Perceived Value

e-Commerce
Most cited work

Chumpitaz Caceres and

Paparoidamis 2007

Meyer-Waarden 2008

Yi and La 2004

McAlexander et al. 2002

Cretu and Brodie 2007 Jin et al. 2008

* Cluster 1: Density: 85.59 Density range: 1 Centrality: 102.7 Centrality range: 1

** Cluster 2: Density: 14.63 Density range: 0.83 Centrality: 58.54 Centrality range: 0.83

Figure 4. Cluster 1 and cluster 2 (Chumpitaz Caceres and Paparoidamis 2007; Kumara and Shah 2004).

The central node of the third cluster is the brand community (Figure 5). A brand community is generally defined as a customer-customer-brand triad (Muniz and O'guinn 2001). The social aggregation of brand users and their relationships to the brand itself spread widely thanks to social media that favor interactions and information sharing. Participation in a brand community represents one of the main expressions of customer engagement that in these contexts is manifested through behaviors, such as the word-of-mouth. The interactions between consumers and companies within the brand communities often take the form of value co-creation paths. Value co-creation was introduced by the Service-Dominat logic (Vargo and Lusch 2004, 2008), which defines it as the creation of a joint value through the application of competences and the integration of resources between the firm and the customer.

In cluster 4, consumer-perception is the concept around which many other topics are analyzed (Figure 5). Consumers' perceptions about a company are mainly determined by the brand image but also by the brand equity. Brand equity represents the customer's subjective and intangible perceptions and attitudes about the brand and it tends to represent the emotional and irrational aspects of the market offering that connect the customer with the brand. Consumers' perceptions are also affected by the corporate social responsibility of the firm, which positively influences the benefit and the value perceived by the consumer in the company's offer, the judgment of fairness in the price differential charged for it, and his/her buying intention, in a context where the socially responsible firm practices a price higher than the competition. Positive consumers' perceptions about a firm or a brand represent a determinant of the purchase intentions, thus increasing the customer value. 


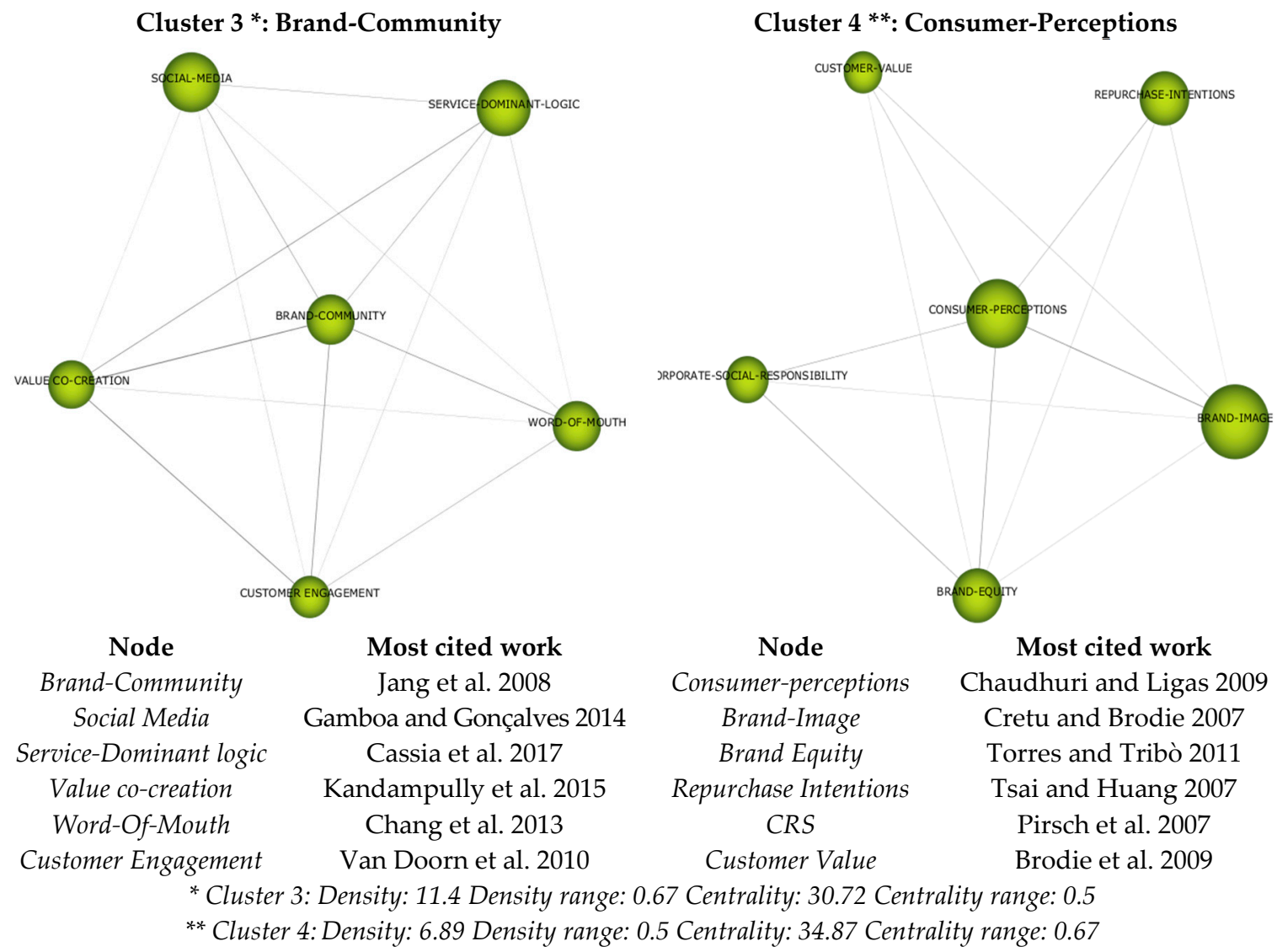

Figure 5. Cluster 3 and cluster 4 .

Cluster 5 is focused on the consumer behaviors that depend on the customer involvement and the customer experience with the brand (Figure 6). Customer involvement motivates consumers to identify with product/service offerings, their consumption patterns, and consumption behavior. Involvement creates an urge within consumers to look for and think about the product/service category and the varying options before making decisions on brand preferences and the final act of purchase. It determinates the amount of physical and mental effort that a consumer puts into a purchase decision, thus influencing the decision-making process of consumers, particularly the purchasing decisions. These decisions also influence the choice of the store, for this reason these variables are studied above all in the retail context.

Finally, in cluster 6 the central node is represented by the competitive advantage of the firm (Figure 6). The achievement of a sustainable competitive advantage depends on the ability of the firm to increase the switching costs for the customers to dissuade them from switching to a competitor's product, brand, or services and thus enhancing the customer retention. Greater customer retention as well as lower customer sensitivity to company's prices have positive effects on customer equity in terms of the total combined customer lifetime values of the company's customers. Finally, firm reputation is one of the most important intangible resources for competitive advantage, because it possesses rarity, value, non-substitutability, and imperfect immutability. Firm reputation influences the perception of the company that is held by consumers, favorably influences new products amongst consumers making purchasing decisions that are more likely to take a risk on a new product if they already know and trust a company with a strong reputation. 


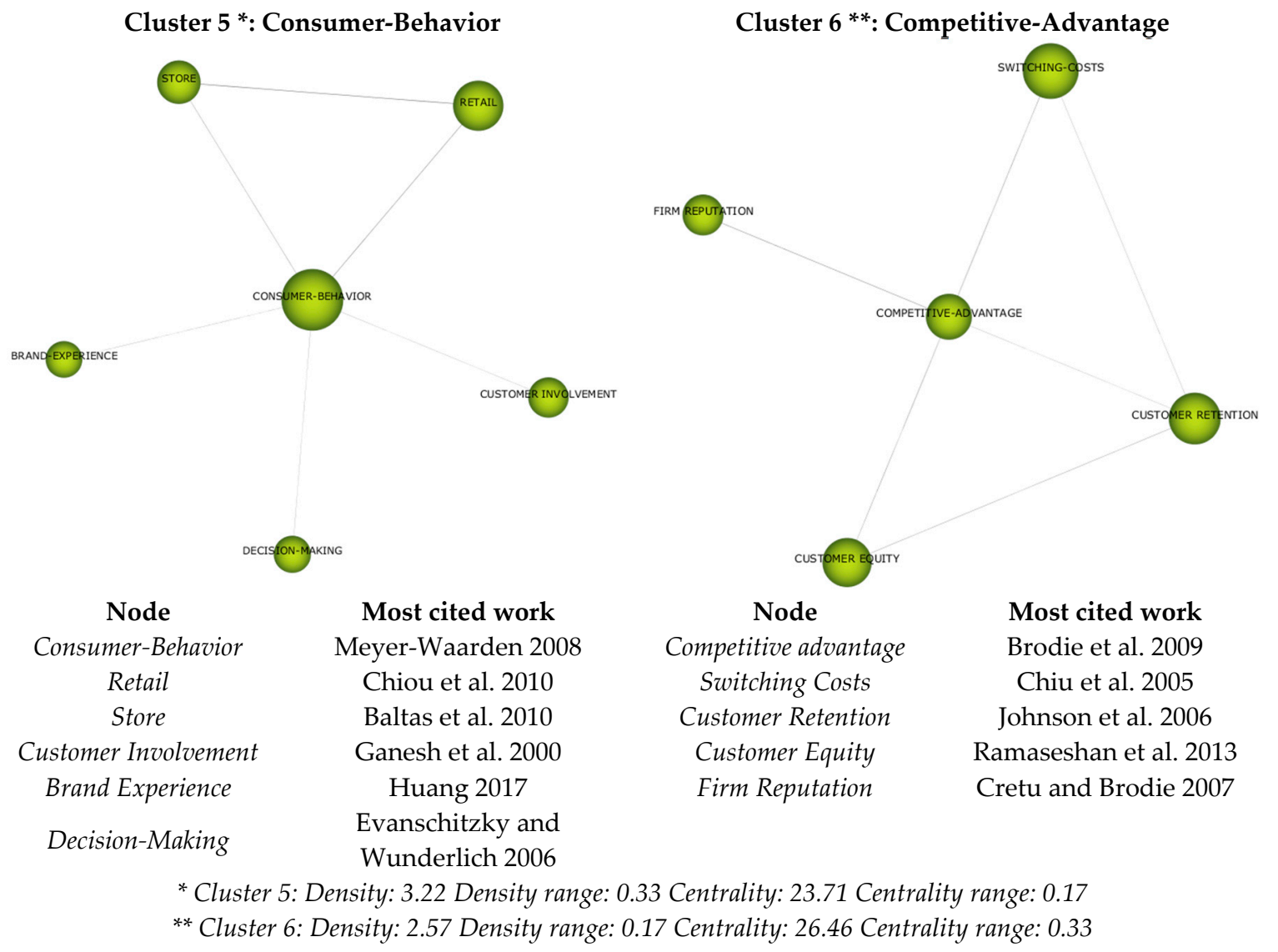

Figure 6. Cluster 5 and cluster 6.

\section{Discussion}

\subsection{Towards a Better Understanding of Customer Loyalty}

Customer loyalty, which generally refers to the strong commitment to repurchase a preferred product or service (Kim et al. 2018b), is one of the most debated topics in management and marketing literature. The interest of scholars about customer loyalty started from 2000 and it is still growing in the scientific community. By analyzing the contributions in this research area, it emerges that the interest of scholars is focused on the analysis of the attitudinal and behavioral dimensions of customer loyalty (Oliver 2014), its antecedents and consequences (Kim et al. 2018c), the evolution of the concept after social changes and ITCs advancements (Yoshida et al. 2018), and on the different strategies that are implemented by companies for its enhancement (Han et al. 2018).

Attitudinal loyalty refers to the customer attachment to a product, brand, or organization (McManus and Guilding 2008), price tolerance (Sánchez et al. 2011), and purchase intention (Kim and Ko 2012). These variables allow for estimating consumers' future behaviors on the basis of their attitudes (Kim and Lee 2009; Kim and Ko 2010).

The behavioral component of loyalty focuses on repeated purchases (Richard and Zhang 2012), positive word-of-mouth (Hajli et al. 2017), and customer equity (Kim and Ko 2012).

Among the principal antecedents of customer loyalty, authors recognize customer satisfaction, commitment, and trust. Customer satisfaction is the principal variable that is related to customer loyalty, since several authors state that satisfied customers tend to remain loyal to a firm or brand (Schultz and Bailey 2000; Caruana 2002; Chumpitaz and Paparoidamis 2004; Smith and Wright 2004; Huang et al. 2006; Richard and Zhang 2012). Customer satisfaction is defined as the positive evaluation of the consumption experience (Anderson et al. 2004), which derives by the difference between the prior expectations and the perceptions after consumption (Tu et al. 2012). Several studies show the 
positive correlation between satisfaction and loyalty (Chen 2008; Chang and Hung 2013; Nesset and Helgesen 2014; Akamavi et al. 2015) and the results of some empirical analyses indicate that customer satisfaction exerts stronger effects on the behavioral loyalty (Rajaguru 2016; Koklic et al. 2017; Shahid Iqbal et al. 2018). Both cognitive and affective satisfaction are considered when they are related to customer loyalty (Coursaris and Osch 2016; Gallarza et al. 2016).

Satisfaction enhances commitment because satisfied customers are more favorable to continue the relationship (Ranaweera and Menon 2013; Jeong and Oh 2017), enjoying benefits like reduced search cost and lower perceived risks (Hess and Story 2005). Relationship commitment is defined as the development of a relationship based on cooperative sentiments, strong preference for existing partners, and propensity for relation continuity (Han et al. 2018).

According to Hajli et al. (2017), consumer trust is another dimension that is able to improve the relationship quality, thus positively affecting customer relationship commitment and customer loyalty (Huang et al. 2006; Ng 2013). Consumer trust refers to the credibility and reliability of the company that determine the conviction in consumers that the company will provide the promised product or service as expected (Sirdeshmukh et al. 2002). In sum, from the literature emerges that customers' loyalty towards a firm or brand increases as trust, commitment, and satisfaction levels increase (Sitorus and Yustisia 2018).

In past decade, the interest of scholars focused on another dimension strongly related to those described above, which is customer engagement. Customer engagement is defined as the intensity of the customer's participation in the relationship with the organization (Patterson et al. 2006). Several authors have considered as consequences of customer engagement the dimensions of trust (Casaló et al. 2007; Hollebeek 2011), satisfaction (Bowden 2009a), commitment (Chan and Li 2010), and loyalty (Bowden 2009a, 2009b). Bowden (2009a) describes engagement as an iterative process that starts with customer satisfaction, transits for commitment and trust, and culminates in customer loyalty.

Related to the concept of customer engagement, value co-creation is proposed as a process for engaging customers in creating value (Prahalad and Ramaswamy 2004) transforming them from passive customers to active players (Vargo and Lusch 2004). Value co-creation is defined by Service-Dominant logic as the application of competences and the integration of resources between users and providers during service delivery (Vargo and Lusch 2004, 2008).

Studies on customer engagement have increased with the development of the social media (Gummerus et al. 2012; Sashi 2012; Zhang and Luo 2016) that facilitate the interactions (Wirtz et al. 2013), collaboration (Laroche et al. 2012), and participation (Algesheimer et al. 2005) between customers and other members of the communities and firms. Moreover, social media favor behaviors of engaged customers, like word-of-mouth, recommendations, activities in support of other consumers, blogging, and product reviews (Van Doorn et al. 2010; Zhang and Luo 2016), which are connected to the customer behavioral loyalty. In the last few years, the concept of social media engagement has developed as the consumer's behavioral manifestations that have a social media focus, beyond purchase, resulting from motivational drivers (Van Doorn et al. 2010; Dolan et al. 2016). Several researches show that social media engagement enhances customer loyalty in terms of both loyalty intentions (Calder et al. 2009; Jahn and Kunz 2012; Hollebeek et al. 2014; Lim et al. 2015) and behavioral loyalty manifestations (Brodie et al. 2013; Dolan et al. 2016).

Some authors state that satisfaction by itself does not determines customer loyalty if it is not accompanied by switching barriers that make the alternative offerings less attractive (Jones et al. 2000; Balabanis et al. 2006; López-Miguens and Vázquez 2017). Picón et al. (2014) found that perceived switching costs are significant mediators in the relationship between satisfaction and loyalty. Other works demonstrate that switching costs have direct and positive effects on customer loyalty (Chang and Chen 2008; Ghazali et al. 2016; Teng 2018).

Finally, from the analysis, it emerges the important role of companies in managing effective strategies of Customer Relationship Management to maintain and increase the quality of the relationship. The quality of the relationship, in terms of its intensity and tightness, influences customer 
loyalty (Palmatier et al. 2006; Yadav et al. 2013). According to Palmatier et al. (2006), the relationship quality is based on the dimensions of trust, commitment, and satisfaction, which represent the dimensions to enhance through branding activities and value co-creation paths in order to achieve customer loyalty (Hajli et al. 2017). By enhancing loyalty, CRM allows firm to achieve a sustainable competitive advantage (Grönroos 2009). Companies gain considerable benefits from retaining an existing customer (Brunner et al. 2008). The ability to maintain long-term customer relationships contribute to an increase in the revenue and a reduction of the costs to companies (Gallo 2014), such as the high costs of acquiring a new customer (Edvardsson et al. 2000; Smith and Wright 2004).

In conclusion, customer loyalty is a very complex area of study because it includes several interrelated and mutually dependent variables. The efforts of the scientific community up to now have been directed to the identification of these variables, the relationships between them, and their influence on customer loyalty. Table 3 summarizes the variables that have were studied by the analyzed works and their role in explaining the customer loyalty and its dimensions.

Table 3. Variables and dimensions of customer loyalty.

\begin{tabular}{|c|c|c|}
\hline \multicolumn{3}{|r|}{ The Explanation of Customer Loyalty } \\
\hline \multirow{4}{*}{$\begin{array}{l}\text { Customer } \\
\text { loyalty as } \\
\text { attitudinal }\end{array}$} & Customer attachment & (McManus and Guilding 2008; Kim and Ko 2010; Kim and Lee 2009) \\
\hline & Price tolerance & (Sánchez et al. 2011; Anderson and Srinivasan 2003; Yi and La 2004) \\
\hline & Repurchase intentions & (Tsai and Huang 2007; Kim and Ko 2012; Tsai and Huang 2007) \\
\hline & $\begin{array}{l}\text { Disinterest towards } \\
\text { competitors' offerings }\end{array}$ & (Evanschitzky et al. 2006; Evanschitzky et al. 2012; Kang et al. 2015) \\
\hline \multirow{4}{*}{$\begin{array}{l}\text { Customer } \\
\text { loyalty as } \\
\text { behavioral }\end{array}$} & Repeated purchases & (Forgas-Coll et al. 2014; Richard and Zhang 2012; Evanschitzky et al. 2006) \\
\hline & Positive word-of-mouth & (Meyer-Waarden 2008; Hajli et al. 2017; Chang et al. 2013) \\
\hline & Customer equity & (Ramaseshan et al. 2013; Kim and Ko 2012) \\
\hline & Decision-making & (Evanschitzky and Wunderlich 2006; Sashi 2012; Zhang et al. 2014) \\
\hline \multicolumn{3}{|r|}{ The Dimensions of Customer Loyalty } \\
\hline \multirow{13}{*}{$\begin{array}{c}\text { Antecedents } \\
\text { of customer } \\
\text { loyalty }\end{array}$} & Perceived quality & (Frank et al. 2014; Chen 2008; Gallarza et al. 2016) \\
\hline & Perceived value & (Cretu and Brodie 2007; Yi and Jeon 2003; Han et al. 2011) \\
\hline & Customer satisfaction & (Evanschitzky and Wunderlich 2006; Picón et al. 2014; Gronholdt et al. 2000) \\
\hline & Consumer trust & (Lee et al. 2007; Sirdeshmukh et al. 2002; Sitorus and Yustisia 2018) \\
\hline & Relationship quality & (Rauyruen and Miller 2007; Hajli et al. 2017; Huang et al. 2006) \\
\hline & Relationship commitment & (Jeong and Oh 2017; Hess and Story 2005; Evanschitzky et al. 2006) \\
\hline & Customer involvement & (Ganesh et al. 2000; Park et al. 2007; Yi and Jeon 2003) \\
\hline & Consumer-perceptions & (Chaudhuri and Ligas 2009; Cretu and Brodie 2007; Zins 2001) \\
\hline & $\begin{array}{l}\text { Corporate Social } \\
\text { Responsibility }\end{array}$ & (Pirsch et al. 2007; Mandhachitara and Poolthong 2011; Bolton and Mattila 2015) \\
\hline & Customer engagement & (Van Doorn et al. 2010; Verhoef et al. 2010; Patterson et al. 2006) \\
\hline & Value co-creation & (Kandampully et al. 2015; Prahalad and Ramaswamy 2004; Hajli et al. 2017) \\
\hline & Firm Reputation & (Cretu and Brodie 2007; Jin et al. 2008; Ageeva et al. 2018) \\
\hline & Switching Costs & (Chiu et al. 2005; Picón et al. 2014; Ghazali et al. 2016) \\
\hline \multirow{5}{*}{$\begin{array}{c}\text { Consequences } \\
\text { of customer } \\
\text { loyalty }\end{array}$} & Customer Retention & (Johnson et al. 2006; Ganesh et al. 2000; Cooil et al. 2007) \\
\hline & Firm performance & (Yi and La 2004; Smith and Wright 2004; Ciunova-Shuleska et al. 2017) \\
\hline & Customer Value & (Brodie et al. 2009; Cretu and Brodie 2007; Wu and Li 2018) \\
\hline & Competitive advantage & (Brodie et al. 2009; Grönroos 2009; Villanueva et al. 2007) \\
\hline & Costs reduction & (Edvardsson et al. 2000; Smith and Wright 2004; Gallo 2014) \\
\hline
\end{tabular}

\subsection{Customer Loyalty and Brand Management}

Brand management plays a fundamental role in the development of customer loyalty. Sometimes, consumers are not loyal to the company in general, but rather to a specific brand. Brand loyalty is commonly connoted as "the biased (non-random) behavioral response (purchase), expressed over time 
by some decision-making unit with respect to one or more alternative brands out of a set of brands and is a function of psychological processes" (Jacoby 1971, p. 25).

Several works show that customer satisfaction improves brand loyalty (Gronholdt et al. 2000; Lee et al. 2009; Nam et al. 2011; Sahin et al. 2011). According to Han et al. (2018), the correlation between satisfaction and brand loyalty is mediated by the relationship commitment. Committed customers feel an emotional attachment towards a brand and they have behaviors like repurchasing, positive recommendations, and disinterest towards competitors' offerings (Evanschitzky et al. 2006); all of these dimensions can be related to the behavioral brand loyalty (Saleem and Raja 2014).

Brand loyalty also depends on the ability of firms to build a strong brand identity through corporate communication strategies, because, as highlighted by Melewar et al. (2017), the more favorable the brand identity is perceived by consumers, the more favorable the attitude consumers have towards the brand strategy.

In last years, in the context of social media, the concept of (online) brand community emerged as the "specialized, non-geographically bound community, based on a structured set of social relationships among admirers of a brand" (Muniz and O'guinn 2001, p. 412). The commitment to a brand community characterizes customers with a strong brand identification, self-identification, and satisfaction with the brand (Park et al. 2007), who purchase the same brand consistently (Algesheimer et al. 2005). Moreover, the committed participation and interactions with other members improves consumers' brand experience and value, leading to enhance their brand commitment (Jang et al. 2008; Kim et al. 2008a) and brand loyalty (Zhou et al. 2012). According to several authors, brand communities also boost the brand engagement (Sprott et al. 2009; Mollen and Wilson 2010; Vivek et al. 2012; Hollebeek et al. 2014), defined by Hollebeek (2011, p. 6) as "the level of a customer's motivational, brand-related, and context-dependent state of mind characterized by specific levels of cognitive, emotional, and behavioral activity in brand interactions."

The commitment to a brand community also has positive effects on brand equity, defined as "the differential effect that brand knowledge has on consumer response to the marketing of that brand" (Keller 1993, p. 8). Several contributions have shown that brand equity includes perceived quality, brand image, and brand loyalty (Dioko and So 2012; Horng et al. 2012; Hsu et al. 2012; Kimpakorn and Tocquer 2010; Manthiou et al. 2014; Nam et al. 2011; Oh and Hsu 2014; Šerić et al. 2014; Xu and Chan 2010). Brand image is a set of perceptions of a consumer that identifies the representation of the brand in his/her mind (Dobni and Zinkhan 1990). Some studies indicate that brand image influences brand loyalty through perceived quality (Chen and Myagmarsuren 2010; Sean Hyun and Kim 2011; Im et al. 2012; Kladou and Kehagias 2014). Perceived quality can be understood as the comparison between firm's performance and customer's expectations (Parasuraman et al. 1988); when the disconfirmation is negative, dissatisfaction is created, when it is positive, customer satisfaction is generated, thus increasing customer loyalty. The concept of perceived quality is strongly related to that of perceived value, which is defined as the consumer's overall evaluation of the benefits that are attained from a product or service in return of the perceived cost, in terms of monetary and non-monetary price (Monroe 2002). The perceived value, in addition to increase customer satisfaction, encourages the consumers' repurchases (Han et al. 2011), promotes re-patronage intentions, and discourages switching behaviors (Wathne et al. 2001), thus improving customer loyalty (Nguyen et al. 2018).

Therefore, from this study, it emerges that also in the case of brand management there are many variables and dimensions related to the brand that are able to affect customer loyalty. The study of these variables and their relationships is fundamental for understanding how to manage the brand in order to increase customer loyalty. The various variables and dimensions of the brand studied by scholars in relation to the customer loyalty are shown in Table 4, reporting the most relevant works for each of them. 
Table 4. Brand variables and dimensions affecting customer loyalty.

\begin{tabular}{ll}
\hline $\begin{array}{l}\text { Variables and Dimensions } \\
\text { Affecting Customer Loyalty }\end{array}$ & Most Relevant Works \\
\hline Brand loyalty & (Yi and Jeon 2003; Nam et al. 2011; Han et al. 2018) \\
Brand engagement & (Mollen and Wilson 2010; Vivek et al. 2012; Hollebeek et al. 2014) \\
Brand community & (Jang et al. 2008; McAlexander et al. 2002; Muniz and O'guinn 2001) \\
Brand commitment & (Park et al. 2007; Jang et al. 2008; Kim et al. 2008a) \\
Brand equity & (Torres and Tribó 2011; Hsu et al. 2012; Manthiou et al. 2014) \\
Brand image & (Cretu and Brodie 2007; Han et al. 2008; Kladou and Kehagias 2014) \\
Brand experience & (Huang 2017; Iglesias et al. 2011; Sahin et al. 2011) \\
\hline
\end{tabular}

\section{Conclusions}

The research on customer loyalty has produced interesting results in terms of clarification of its dimensions. As attitudinal dimensions, scholars have identified the involvement and attachment to a firm or brand and the price tolerance, while as behavioral dimensions, the repurchasing behavior, positive recommendations, and word-of-mouth. However, it emerges that more studies are needed for measuring the combined effects of the two class of dimensions on loyalty.

Customer satisfaction, commitment, trust, and engagement have been detected as the principal variables that are related to loyalty. Relationships between these variables have been investigated through the definition of empirical models and quantitative analyses, which show positive correlations between them. All of the variables exert positive effects on customer loyalty, and at the same time, loyalty has a positive influence on all them. These results suggest overcoming the distinction between loyalty antecedents and consequences in favor of a consideration of the different variables in a positive circle in which the improvement of one variable triggers a chain reaction of improvements. All of the psychological processes comprise cognitive and emotional aspects and both enhance the behavioral loyalty. Hence, companies must pay more attention to the emotional content in the relationships.

Brand management becomes more and more important for the loyalty improvements. In fact, new concepts have been introduced, like brand loyalty, brand engagement, brand equity, and brand communities. Brand is recognized as the principal factor that is able to create commitment and engage customers. Particular attention is devoted to the online brand communities as environments where new forms of consumers-to-consumers communication emerge, allowing for new forms of brand identification and brand experiences that enhance the brand value and the consumers' attachment to the brand. Brand communities thus become the most important tool for CRM strategies. The participation of companies in brand communities allow them to acquire the necessary information, share and emphasize contents, target the consumers, and increase the brand equity. According to the results of Zhou et al. (2012), companies should support brand community providing resources (e.g., funds, staff, and place), cultivating a cohesive brand community and providing not only material assistance, but also care and rewards to the brand community. Moreover, companies should propose some activities for the members of the community according to the style, personality, feeling, and values of the brand.

Generally, all social media are indicated as places where the relationships with customers are managed, as they provide more opportunities of interaction and information sharing allowing the customer engagement and activating value co-creation paths with them. Through social media, firms can facilitate the social interactions of customers for branding co-creation, knowledge sharing, and customer empowerment (Andersen 2005; Ramaswamy 2009).

From these considerations, useful suggestions for future research emerge. First, despite the variables influencing customer loyalty have been well identified by previous works, there is a need for further empirical research on the relationships between them. A confusion about how these variables influence each other before exerting their effect on customer loyalty is still detected. New studies should be carried out in the social media that offer a large amount of information and evidences about the attitudes and behaviors of consumers that could be studied, for example, with sentiment 
and content analyses. Second, to keep up with the latest advancements in marketing, future research should focus on those variables that allow for studying the role of consumers as active co-creators of a higher value in a perspective of mutual benefit with the firm. Topics, such as customer engagement and value co-creation, should therefore acquire a dominant position in future studies.

Author Contributions: Although the paper is the result of a synergic work, it is attributed to A.M.T. the Sections 3.1 and 4.2, to Y.C. the Sections 3.2 and 4.1, to G.R. the Sections 1 and 2, and to G.G. the Section 5.

Funding: This research received no external funding.

Conflicts of Interest: The authors declare no conflict of interest.

\section{References}

Ageeva, Elena, T. C. Melewar, Pantea Foroudi, Charles Dennis, and Zhongqi Jin. 2018. Examining the influence of corporate website favorability on corporate image and corporate reputation: Findings from fsQCA. Journal of Business Research 89: 287-304. [CrossRef]

Akamavi, Raphaël K., Elsayed Mohamed, Katharina Pellmann, and Yue Xu. 2015. Key determinants of passenger loyalty in the low-cost airline business. Tourism Management 46: 528-45. [CrossRef]

Algesheimer, René, Utpal M. Dholakia, and Andreas Herrmann. 2005. The social influence of brand community: Evidence from European car clubs. Journal of Marketing 69: 19-34. [CrossRef]

Andersen, Poul Houman. 2005. Relationship marketing and brand involvement of professionals through web-enhanced brand communities: The case of Coloplast. Industrial Marketing Management 34: 39-51. [CrossRef]

Anderson, Rolph E., and Srini S. Srinivasan. 2003. E-satisfaction and e-loyalty: A contingency framework. Psychology and Marketing 20: 123-38. [CrossRef]

Anderson, Eugene W., Claes Fornell, and Sanal K. Mazvancheryl. 2004. Customer satisfaction and shareholder value. Journal of Marketing 68: 172-85. [CrossRef]

Balabanis, George, Nina Reynolds, and Antonis Simintiras. 2006. Bases of e-store loyalty: Perceived switching barriers and satisfaction. Journal of Business Research 59: 214-24. [CrossRef]

Ball, Dwayne, Pedro Simões Coelho, and Alexandra Machás. 2004. The role of communication and trust in explaining customer loyalty: An extension to the ECSI model. European Journal of Marketing 38: 1272-93. [CrossRef]

Baltas, George, Paraskevas C. Argouslidis, and Dionysis Skarmeas. 2010. The role of customer factors in multiple store patronage: A cost-Benefit approach. Journal of Retailing 86: 37-50. [CrossRef]

Bolton, Lisa E., and Anna S. Mattila. 2015. How Does Corporate Social Responsibility Affect Consumer Response to Service Failure in Buyer-Seller Relationships? Journal of Retailing 91: 140-53. [CrossRef]

Börner, Katy, Chaomei Chen, and Kevin W. Boyack. 2003. Visualizing knowledge domains. Annual Review of Information Science and Technology 37: 179-255. [CrossRef]

Bowden, Jana Lay-Hwa. 2009a. The process of customer engagement: A conceptual framework. Journal of Marketing Theory and Practice 17: 63-74. [CrossRef]

Bowden, Jana Lay-Hwa. 2009b. Customer engagement: A framework for assessing customer-brand relationships: The case of the restaurant industry. Journal of Hospitality Marketing and Management 18: 574-96. [CrossRef]

Brodie, Roderick J., James RM Whittome, and Gregory J. Brush. 2009. Investigating the service brand: A customer value perspective. Journal of Business Research 62: 345-55. [CrossRef]

Brodie, Roderick J., Ana Ilic, Biljana Juric, and Linda Hollebeek. 2013. Consumer engagement in a virtual brand community: An exploratory analysis. Journal of Business Research 66: 105-14. [CrossRef]

Brunner, Thomas A., Markus Stöcklin, and Klaus Opwis. 2008. Satisfaction, image and loyalty: New versus experienced customers. European Journal of Marketing 42: 1095-105. [CrossRef]

Calder, Bobby J., Edward C. Malthouse, and Ute Schaedel. 2009. An experimental study of the relationship between online engagement and advertising effectiveness. Journal of Interactive Marketing 23: 321-31. [CrossRef]

Calero Medina, C. M., and Thed N. van Leeuwen. 2012. Seed Journal Citation Network Maps: A Method Based on Network Theory. Journal of the American Society for Information Science and Technology 63: 1226-34. [CrossRef]

Caruana, Albert. 2002. Service loyalty: The effects of service quality and the mediating role of customer satisfaction. European Journal of Marketing 36: 811-29. [CrossRef] 
Casaló, Luis, Carlos Flavián, and Miguel Guinalíu. 2007. The impact of participation in virtual brand communities on consumer trust and loyalty: The case of free software. Online Information Review 34: 775-92. [CrossRef]

Cassia, Fabio, Nicola Cobelli, and Marta Ugolini. 2017. The effects of goods-related and service-related B2B brand images on customer loyalty. Journal of Business \& Industrial Marketing 32: 722-32.

Castillo-Vergara, Mauricio, Alejandro Alvarez-Marin, and Dario Placencio-Hidalgo. 2018. A bibliometric analysis of creativity in the field of business economics. Journal of Business Research 85: 1-9. [CrossRef]

Chan, Kimmy Wa, and Stella Yiyan Li. 2010. Understanding consumer-to-consumer interactions in virtual communities: The salience of reciprocity. Journal of Business Research 63: 1033-40. [CrossRef]

Chang, Hsin Hsin, and Su Wen Chen. 2008. The impact of customer interface quality, satisfaction and switching costs on e-loyalty: Internet experience as a moderator. Computers in Human Behavior 24: 2927-44. [CrossRef]

Chang, Li-Yen, and Shao-Chih Hung. 2013. Adoption and loyalty toward low cost carriers: The case of Taipei-Singapore passengers. Transportation Research Part E: Logistics and Transportation Review 50: 29-36. [CrossRef]

Chang, Aihwa, Sara H. Hsieh, and Timmy H. Tseng. 2013. Online Brand community response to negative brand events: The role of group eWOM. Internet Research 23: 486-506. [CrossRef]

Chaudhuri, Arjun, and Mark Ligas. 2009. Consequences of Value in Retail Markets. Journal of Retailing 85: 406-19. [CrossRef]

Chen, Ching-Fu. 2008. Investigating structural relationships between service quality, perceived value, satisfaction, and behavioral intentions for air passengers: Evidence from Taiwan. Transportation Research Part A: Policy and Practice 42: 709-17. [CrossRef]

Chen, Ching-Fu, and Odonchimeg Myagmarsuren. 2010. Exploring relationships between Mongolian destination brand equity, satisfaction and destination loyalty. Tourism Economics 16: 981-94. [CrossRef]

Chen, Jin, Cheng Zhang, and Yunjie Xu. 2009. The Role of Mutual Trust in Building Members' Loyalty to a C2C Platform Provider. International Journal of Electronic Commerce 14: 147-71. [CrossRef]

Chiou, Jyh-Shen, Lei-Yu Wu, and Min-Chieh Chuang. 2010. Antecedents of retailer loyalty: Simultaneously investigating channel push and consumer pull effects. Journal of Business Research 63: 431-38. [CrossRef]

Chiu, Hung-Chang, Yi-Ching Hsieh, Yu-Chuan Li, and Monle Lee. 2005. Relationship Marketing and Consumer Switching Behavior. Journal of Business Research 58: 1681-89. [CrossRef]

Chumpitaz, Ruben, and Nicholas G. Paparoidamis. 2004. Service quality and marketing performance in business-to-business markets: Exploring the mediating role of client satisfaction. Managing Service Quality 14: 235-48. [CrossRef]

Chumpitaz Caceres, Ruben, and Nicholas G. Paparoidamis. 2007. Service Quality, Relationship Satisfaction, Trust, Commitment and Business-to-Business Loyalty. European Journal of Marketing 41: 836-67. [CrossRef]

Ciunova-Shuleska, Anita, Nikolina Palamidovska-Sterjadovska, C. Nedu Osakwe, and J. Omotoso. 2017. The impact of customer retention orientation and brand orientation on customer loyalty and financial performance in SMEs: Empirical evidence from a Balkan country. Journal for East European Management Studies 22: 83-104. [CrossRef]

Cobo, Manolo J., Antonio Gabriel López-Herrera, Enrique Herrera-Viedma, and Francisco Herrera. 2012. SciMAT: A new science mapping analysis software tool. Journal of the American Society for Information Science and Technology 63: 1609-30. [CrossRef]

Cooil, Bruce, Timothy L. Keiningham, Lerzan Aksoy, and Michael Hsu. 2007. A longitudinal analysis of customer satisfaction and share of wallet: Investigating the moderating effect of customer characteristics. Journal of Marketing 71: 67-83. [CrossRef]

Coursaris, Constantinos K., and Wietske van Osch. 2016. A Cognitive-affective model of perceived user satisfaction (CAMPUS): The complementary effects and interdependence of usability and aesthetics in IS design. Information $\mathcal{E}$ Management 53: 252-64.

Cretu, Anca E., and Roderick J. Brodie. 2007. The influence of brand image and company reputation where manufacturers market to small firms: A customer value perspective. Industrial Marketing Management 36: 230-40. [CrossRef]

Dick, Alan S., and Kunal Basu. 1994. Customer loyalty: Toward an integrated conceptual framework. Journal of Academy Marketing Science 22: 99-113. [CrossRef] 
Dioko, Leonardo Don AN, and Siu-Ian Amy So. 2012. Branding destinations versus branding hotels in a gaming destination: Examining the nature and significance of co-branding effects in the case study of Macao. International Journal of Hospitality Management 31: 554-63. [CrossRef]

Dobni, Dawn, and George M. Zinkhan. 1990. In search of brand image: A foundation analysis. Adv. Cons. Res 17: 110-19.

Dolan, Rebecca, Jodie Conduit, John Fahy, and Steve Goodman. 2016. Social media engagement behaviour: A uses and gratifications perspective. Journal of Strategic Marketing 24: 261-77. [CrossRef]

Edvardsson, Bo, Michael D. Johnson, Anders Gustafsson, and Tore Strandvik. 2000. The effects of satisfaction and loyalty on profits and growth: Products versus services. Total Quality Management 11: 917-27. [CrossRef]

Evanschitzky, Heiner, and Maren Wunderlich. 2006. An examination of moderator effects in the four-stage loyalty model. Journal of Service Research 8: 330-345. [CrossRef]

Evanschitzky, Heiner, Gopalkrishnan R. Iyer, Hilke Plassmann, Joerg Niessing, and Heribert Meffert. 2006. The relative strength of affective commitment in securing loyalty in service relationships. Journal of Business Research 59: 1207-13. [CrossRef]

Evanschitzky, Heiner, Balasubramanian Ramaseshan, David M. Woisetschläger, Verena Richelsen, Markus Blut, and Christof Backhaus. 2012. Consequences of customer loyalty to the loyalty program and to the company. Journal of the Academy of Marketing Science 40: 625-38. [CrossRef]

Fetscherin, Marc, and Daniel Heinrich. 2015. Consumer brand relationships research: A bibliometric citation meta-analysis. Journal of Business Research 68: 380-90. [CrossRef]

Fetscherin, Marc, and Jean-Claude Usunier. 2012. Corporate branding: An interdisciplinary literature review. European Journal of Marketing 46: 733-53. [CrossRef]

Forgas-Coll, Santiago, Ramon Palau-Saumell, Javier Sánchez-García, and Eva Maria Caplliure-Giner. 2014. The role of trust in cruise passenger behavioral intentions: The moderating effects of the cruise line brand. Management Decision 52: 1346-67. [CrossRef]

Frank, Björn, Boris Herbas Torrico, Takao Enkawa, and Shane J. Schvaneveldt. 2014. Affect versus cognition in the chain from perceived quality to customer loyalty: The roles of product beliefs and experience. Journal of Retailing 90: 567-86. [CrossRef]

Fullerton, Gordon. 2005. The impact of brand commitment on loyalty to retail service brands. Canadian Journal of Administrative Sciences 22: 97-110. [CrossRef]

Gallarza, Martina G., Maria Eugenia Ruiz-Molina, and Irene Gil-Saura. 2016. Stretching the value-satisfactionloyalty chain by adding value dimensions and cognitive and affective satisfactions: A causal model for retailing. Management Decision 54: 981-1003. [CrossRef]

Gallo, Amy. 2014. The Value of Keeping the Right Customers. Harvard Business Review, October 29.

Gamboa, Ana Margarida, and Helena Martins Gonçalves. 2014. Customer loyalty through social networks: Lessons from Zara on Facebook. Business Horizons 57: 709-17. [CrossRef]

Ganesh, Jaishankar, Mark J. Arnold, and Kristy E. Reynolds. 2000. Understanding the customer base of service providers: An examination of the differences between switchers and stayers. Journal of Marketing 64: 65-87. [CrossRef]

Gensler, Sonja, Franziska Völckner, Yuping Liu-Thompkins, and Caroline Wiertz. 2013. Managing brands in the social media environment. Journal of Interactive Marketing 27: 242-56. [CrossRef]

Ghazali, Ezlika, Bang Nguyen, Dilip S. Mutum, and Amrul Asraf Mohd-Any. 2016. Constructing online switching barriers: Examining the effects of switching costs and alternative attractiveness on e-store loyalty in online pure-play retailer. Electronic Markets 26: 157-71. [CrossRef]

Gronholdt, Lars, Anne Martensen, and Kai Kristensen. 2000. The relationship between customer satisfaction and loyalty: Cross-industry differences. Total Quality Management 11: 509-14. [CrossRef]

Grönroos, Christian. 2009. Marketing as promise management: Regaining customer management for marketing. Journal of Business $\mathcal{E}$ Industrial Marketing 24: 351-59.

Gummerus, Johanna, Veronica Liljander, Emil Weman, and Minna Pihlström. 2012. Customer engagement in a Facebook brand community. Management Research Review 35: 857-77. [CrossRef]

Gustafsson, Anders, Michael D. Johnson, and Inger Roos. 2005. The effects of customer satisfaction, relationship commitment dimensions, and triggers on customer retention. Journal Marketing 69: 210-18. [CrossRef]

Hajli, Nick, Mohana Shanmugam, Savvas Papagiannidis, Debra Zahay, and Marie-Odile Richard. 2017. Branding co-creation with members of online brand communities. Journal of Business Research 70: 136-44. [CrossRef] 
Han, Xiaoyun, Robert J. Kwortnik Jr., and Chunxiao Wang. 2008. Service loyalty: An integrative model and examination across service contexts. Journal of Service Research 11: 22-42.

Han, Heesup, Yunhi Kim, and Eui-Keun Kim. 2011. Cognitive, affective, conative, and action loyalty: Testing the impact of inertia. International Journal of Hospitality Management 30: 1008-19. [CrossRef]

Han, Heesup, Hong Ngoc Nguyen, Hakjun Song, Bee-Lia Chua, Sanghyeop Lee, and Wansoo Kim. 2018. Drivers of brand loyalty in the chain coffee shop industry. International Journal of Hospitality Management 72: 86-97. [CrossRef]

Hess, Jeff, and John Story. 2005. Trust-based commitment: Multidimensional consumer-brand relationships. Journal of Consumer Marketing 22: 313-22. [CrossRef]

Hollebeek, Linda D. 2011. Demystifying customer brand engagement: Exploring the loyalty nexus. Journal of Marketing Management 27: 785-07. [CrossRef]

Hollebeek, Linda D., Mark S. Glynn, and Roderick J. Brodie. 2014. Consumer brand engagement in social media: Conceptualization, scale development and validation. Journal of Interactive Marketing 28: 149-65. [CrossRef]

Horng, Jeou-Shyan, Chih-Hsing Liu, Hsin-Yu Chou, and Chang-Yen Tsai. 2012. Understanding the impact of culinary brand equity and destination familiarity on travel intentions. Tourism Management 33: 815-24. [CrossRef]

Hsu, Cathy H. C., Haemoon Oh, and A. George Assaf. 2012. A customer-based brand equity model for upscale hotels. Journal of Travel Research 51: 81-93. [CrossRef]

Huang, Chao-Chin. 2017. The impacts of brand experiences on brand loyalty: Mediators of brand love and trust. Management Decision 55: 915-34. [CrossRef]

Huang, Heng-Hsiang, Chou Kang Chiu, and Ching Kuo. 2006. Exploring customer satisfaction, trust and destination loyalty in tourism. Journal of American Academy of Business 10: 156-59.

Sean Hyun, Sunghyup, and Wansoo Kim. 2011. Dimensions of brand equity in the chain restaurant industry. Cornell Hospitality Quarterly 52: 429-37. [CrossRef]

Iglesias, Oriol, Jatinder J. Singh, and Joan M. Batista-Foguet. 2011. The role of brand experience and affective commitment in determining brand loyalty. Journal of Brand Management 18: 570-82. [CrossRef]

Im, Holly Hyunjung, Samuel Seongseop Kim, Statia Elliot, and Heejoo Han. 2012. Conceptualizing the brand equity dimensions from a consumer-based brand equity perspective. Journal of Travel \& Tourism Marketing 29: 385-403.

Jacoby, Jacob. 1971. A model of multi-brand loyalty. Journal of Advertising Research 11: 25-31.

Jahn, Benedikt, and Werner Kunz. 2012. How to transform consumers into fans of your brand. Journal of Service Management 23: 344-61. [CrossRef]

Jang, Heehyoung, Lorne Olfman, Ilsang Ko, Joon Koh, and Kyungtae Kim. 2008. The influence of on-line brand community characteristics on community commitment and brand loyalty. International Journal of Electronic Commerce 3: 57-80. [CrossRef]

Jeong, Miyoung, and Haemoon Oh. 2017. Business-to-business social exchange relationship beyond trust and commitment. International Journal of Hospitality Management 65: 115-24. [CrossRef]

Jin, Byoungho, Jin Yong Park, and Jiyoung Kim. 2008. Cross-cultural examination of the relationships among firm reputation, e-satisfaction, e-trust, and e-loyalty. International Marketing Review 25: 324-37. [CrossRef]

Johnson, Michael D., Andreas Herrmann, and Frank Huber. 2006. The evolution of loyalty intentions. Journal of Marketing 70: 122-32. [CrossRef]

Jones, Michael A., David L. Mothersbaugh, and Sharon E. Beatty. 2000. Switching barriers and repurchase intentions in services. Journal of Retailing 76: 259-74. [CrossRef]

Kandampully, Jay, Tingting Zhang, and Anil Bilgihan. 2015. Customer loyalty: A review and future directions with a special focus on the hospitality industry. International Journal of Contemporary Hospitality Management 27: 379-414. [CrossRef]

Kang, Jun, Thomas Brashear Alejandro, and Mark D. Groza. 2015. Customer-company identification and the effectiveness of loyalty programs. Journal of Business Research 68: 464-71. [CrossRef]

Keller, Kevin Lane. 1993. Conceptualizing, Measuring, and Managing Customer-Based Brand Equity. Journal of Marketing 57: 1-22. [CrossRef]

Kim, Angella Ji-Young, and Eun-Ju Ko. 2010. The impact of design characteristics on brand attitude and purchase intention: Focus on luxury fashion brands. Journal of the Korean Society of Clothing and Textiles 34: 252-65. [CrossRef] 
Kim, Angella Ji-Young, and Eun-Ju Ko. 2012. Do social media marketing activities enhance customer equity? An empirical study of luxury fashion brand. Journal of Business Research 65: 1480-86. [CrossRef]

Kim, H. J., and H. Z. Lee. 2009. The effect of well-being, consumer value orientations, perceived value and brand preference on purchase intention of environment-friendly cosmetics. Journal of the Korean Society for Clothing Industry 15: 327-48.

Kim, Jae Wook, Jiho Choi, William Qualls, and Kyesook Han. 2008a. It takes a marketplace community to raise brand commitment: The role of online communities. Journal Marketing Management 3: 409-31. [CrossRef]

Kim, Moon-Koo, Myeong-Cheol Park, Jong-Hyun Park, Jimin Kim, and Eunhye Kim. 2018b. The role of multidimensional switching barriers on the cognitive and affective satisfaction-loyalty link in mobile communication services: Coupling in moderating effects. Computers in Human Behavior 87: 212-23. [CrossRef]

Kim, Seongseop Sam, Ja Young Jacey Choe, and James F. Petrick. 2018c. The effect of celebrity on brand awareness, perceived quality, brand image, brand loyalty, and destination attachment to a literary festival. Journal of Destination Marketing \& Management 9: 320-29.

Kimpakorn, Narumon, and Gerard Tocquer. 2010. Service brand equity and employee brand commitment. Journal of Services Marketing 24: 378-88. [CrossRef]

Kladou, Stella, and John Kehagias. 2014. Assessing destination brand equity: An integrated approach. Journal of Destination Marketing \& Management 3: 2-10.

Koklic, Mateja Kos, Monika Kukar-Kinney, and Spela Vegelj. 2017. An investigation of customer satisfaction with low-cost and full-service airline companies. Journal of Business Research 80: 188-96. [CrossRef]

Kumara, V., and Denish Shah. 2004. Building and sustaining profitable customer loyalty for the 21st century. Journal of Retailing 80: 317-30. [CrossRef]

Laroche, Michel, Mohammad Reza Habibi, Marie-Odile Richard, and Ramesh Sankaranarayanan. 2012. The effects of social media based brand communities on brand community markers, value creation practices, brand trust and brand loyalty. Computers in Human Behavior 28: 1755-67. [CrossRef]

Lee, Kuan-Yin, Hui-Ling Huang, and Yin-Chiech Hsu. 2007. Trust, satisfaction and commitment: On loyalty to international retail service brands. Asia Pacific Management Review 12: 161-69.

Lee, Yong-Ki, Ki-Joon Back, and Jin-Young Kim. 2009. Family restaurant brand personality and its impact on customer's emotion, csatisfaction, and brand loyalty. Journal of Hospitality Tourism Research 33: 305-28. [CrossRef]

Lim, Joon Soo, YoungChan Hwang, Seyun Kim, and Frank A. Biocca. 2015. How social media engagement leads to sports channel loyalty: Mediating roles of social presence and channel commitment. Computers in Human Behavior 46: 158-67. [CrossRef]

Llanos-Herrera, Gonzalo R., and Jose M. Merigo. 2018. Overview of brand personality research with bibliometric indicators. Kybernetes. [CrossRef]

López-Miguens, $\mathrm{M}^{\mathrm{a}}$ Jesús, and Encarnación González Vázquez. 2017. An integral model of e-loyalty from the consumer's perspective. Computers in Human Behavior 72: 397-411. [CrossRef]

Mandhachitara, Rujirutana, and Yaowalak Poolthong. 2011. A model of customer loyalty and corporate social responsibility. Journal of Services Marketing 25: 122-33. [CrossRef]

Manthiou, Aikaterini, Juhee Kang, and Thomas Schrier. 2014. A visitor-based brand equity perspective: The case of a public festival. Tourism Review 69: 264-83. [CrossRef]

Mattila, Anna S. 2001. Emotional bonding and restaurant loyalty. Cornell Hospitality Quarterly 42: 73-79. [CrossRef]

McAlexander, James H., John W. Schouten, and Harold F. Koenig. 2002. Building brand community. Journal of Marketing 66: 38-54. [CrossRef]

McManus, Lisa, and Chris Guilding. 2008. Exploring the potential of customer accounting: A synthesis of the accounting and marketing literatures. Journal of Marketing Management 24: 771-95. [CrossRef]

Melewar, T. C., Pantea Foroudi, Suraksha Gupta, Philip J. Kitchen, and Mohammad M. Foroudi. 2017. Integrating identity, strategy and communications for trust, loyalty and commitment. European Journal of Marketing 51: 572-604. [CrossRef]

Meyer-Waarden, Lars. 2008. The influence of loyalty programme membership on customer purchase behaviour. European Journal of Marketing 42: 87-114. [CrossRef]

Mollen, Anne, and Hugh Wilson. 2010. Engagement, telepresence and interactivity in online consumer experience: Reconciling scholastic and managerial perspectives. Journal of Business Research 63: 919-25. [CrossRef]

Monroe, Kent B. 2002. Pricing, 3rd ed. New York: McGraw-Hill. 
Morris, Steven A., and Betsy Van der Veer Martens. 2008. Mapping research specialties. Annual Review of Information Science and Technology 42: 213-95. [CrossRef]

Muniz, Albert M., and Thomas C. O'guinn. 2001. Brand community. Journal of Consumer Research 27: 412-32. [CrossRef]

Nam, Janghyeon, Yuksel Ekinci, and Georgina Whyatt. 2011. Brand equity, brand loyalty and consumer satisfaction. Annals of Tourism Research 38: 1009-30. [CrossRef]

Nesset, Erik, and Øyvind Helgesen. 2014. Effects of switching costs on customer attitude loyalty to an airport in a multi-airport region. Transportation Research Part A: Policy and Practice 67: 240-53. [CrossRef]

$\mathrm{Ng}$, Celeste See-Pui. 2013. Intention to purchase on social commerce websites across cultures: A cross-regional study. Information Management 50: 609-20. [CrossRef]

Nguyen, Ha Thu, Hoang Nguyen, Nhan Duc Nguyen, and Anh Chi Phan. 2018. Determinants of Customer Satisfaction and Loyalty in Vietnamese Life-Insurance Setting. Sustainability 10: 1151. [CrossRef]

Norris, Michael, and Charles Oppenheim. 2007. Comparing alternatives to the Web of Science for coverage of the social sciences' literature. Journal of Informetrics 1: 161-69. [CrossRef]

Noyons, E., H. Moed, and A. Van Raan. 1999. Integrating research performance analysis and science mapping. Scientometrics 46: 591-604. [CrossRef]

Oh, Haemoon, and Cathy HC Hsu. 2014. Assessing equivalence of hotel brand equity measures in cross-cultural contexts. International Journal of Hospitality Management 36: 156-66. [CrossRef]

Oliver, Richard L. 2014. Satisfaction: A Behavioral Perspective on the Consumer. Abingdon: Routledge.

Palmatier, Robert W., Rajiv P. Dant, Dhruv Grewal, and Kenneth R. Evans. 2006. Factors influencing the effectiveness of relationship marketing: A meta-analysis. Journal of Marketing 70: 136-53. [CrossRef]

Pan, Yue, Simon Sheng, and Frank T. Xie. 2012. Antecedents of customer loyalty: An empirical synthesis and reexamination. Journal of Retailing and Consumer Service 19: 150-58. [CrossRef]

Parasuraman, Ananthanarayanan, Valarie A. Zeithaml, and Leonard L. Berry. 1988. Servqual: A multiple-item scale for measuring consumer perceptions. Journal of Retailing 64: 12.

Park, Do-Hyung, Jumin Lee, and Ingoo Han. 2007. The effect of on-line consumer reviews on consumer purchasing intention: The moderating role of involvement. International Journal of Electronic Commerce 11: 125-48. [CrossRef]

Patterson, Paul, Ting Yu, and Ko De Ruyter. 2006. Understanding Customer Engagement in Services. Advancing Theory, Maintaining Relevance. Paper presented at the ANZMAC 2006 Conference, Brisbane, Australia, December 4-6.

Pentina, Iryna, Bashar S. Gammoh, Lixuan Zhang, and Michael Mallin. 2013. Drivers and outcomes of brand relationship quality in the context of online social networks. International Journal of Electronic Commerce 17: 63-86. [CrossRef]

Picón, Araceli, Ignacio Castro, and José L. Roldán. 2014. The relationship between satisfaction and loyalty: A mediator analysis. Journal of Business Research 67: 746-51. [CrossRef]

Pirsch, Julie, Shruti Gupta, and Stacy Landreth Grau. 2007. A framework for understanding corporate social responsibility programs as a continuum: An exploratory study. Journal of Business Ethics 70: 125-40. [CrossRef]

Prahalad, Coimbatore K., and Venkat Ramaswamy. 2004. Co-creation experiences: The next practice in value creation. Journal of Interactive Marketing 18: 5-14. [CrossRef]

Radler, Viktoria Maria. 2018. 20 Years of brand personality: A bibliometric review and research agenda. Journal of Brand Management 25: 370-83. [CrossRef]

Rajaguru, Rajesh. 2016. Role of value for money and service quality on behavioural intention: A study of full service and low cost airlines. Journal of Air Transportation Management 53: 114-22. [CrossRef]

Ramaseshan, Balasubramanian, Fazlul K. Rabbanee, and Laine Tan Hsin Hui. 2013. Effects of customer equity drivers on customer loyalty in B2B context. Journal of Business $\mathcal{E}$ Industrial Marketing 28: 335-46.

Ramaswamy, Venkat. 2009. Leading the transformation to co-creation of value. Strategy E Leadership 37: 32-37.

Ranaweera, Chatura, and Kalyani Menon. 2013. For better or for worse? European Journal of Marketing 47: $1598-621$. [CrossRef]

Rauyruen, Papassapa, and Kenneth E. Miller. 2007. Relationship quality as a predictor of B2B customer loyalty. Journal of Business Research 60: 21-31. [CrossRef] 
Richard, James E., and Annie Zhang. 2012. Corporate image, loyalty, and commitment in the consumer travel industry. Journal of Marketing Management 28: 568-93. [CrossRef]

Sahin, Azize, Cemal Zehir, and Hakan Kitapç1. 2011. The effects of brand experiences, trust and satisfaction on building brand loyalty: An empirical research on global brands. Procedia-Social and Behavioral Sciences 24: 1288-301. [CrossRef]

Saleem, Hamad, and Naintara Sarfraz Raja. 2014. The impact of service quality on customer satisfaction, customer loyalty and brand image: Evidence from hotel industry of Pakistan. Journal of Business Management 16: 117-22. [CrossRef]

Sánchez, José Ángel López, María Leticia Santos Vijande, and Juan Antonio Trespalacios Gutiérrez. 2011. The effects of manufacturer's organizational learning on distributor satisfaction and loyalty in industrial markets. Industrial Marketing Management 40: 624-35. [CrossRef]

Sashi, C. M. 2012. Customer engagement, buyer-seller relationships, and social media. Management Decision 50: 253-72. [CrossRef]

Schmidt, Frank. 2008. Meta-Analysis: A Constantly Evolving Research Integration Tool. Organizational Research Methods 11: 96-113. [CrossRef]

Schultz, Don E., and Scott E. Bailey. 2000. Customer/brand loyalty in an interactive marketplace. Journal of Advertising Research 40: 41-52. [CrossRef]

Šerić, Maja, Irene Gil-Saura, and María Eugenia Ruiz-Molina. 2014. How can integrated marketing communications and advanced technology influence the creation of customer-based brand equity? Evidence from the hospitality industry. International Journal of Hospitality Management 39: 144-56. [CrossRef]

Shahid Iqbal, Muhammad, Masood Ul Hassan, and Ume Habibah. 2018. Impact of self-service technology (SST) service quality on customer loyalty and behavioural intention: The mediating role of customer satisfaction. Cogent Business \& Management 5: 1423770.

Sirdeshmukh, Deepak, Jagdip Singh, and Barry Sabol. 2002. Customer Trust, Value and Loyalty in Relational Exchanges. Journal of Marketing 66: 15-37. [CrossRef]

Siemieniako, Dariusz. 2018. Bibliometric Analysis of Scientific Research on Customer Loyalty in the Business-toBusiness Context. Handel Wewnętrzny 5: 257-67.

Sitorus, Tigor, and Milawati Yustisia. 2018. The influence of service quality and customer trust toward customer loyalty: The role of customer satisfaction. International Journal for Quality Research 12: 639-54.

Small, Henry. 1999. Visualizing science by citation mapping. Journal of the American Society for Information Science and Technology 50: 799-813. [CrossRef]

Smith, Rodney E., and William F. Wright. 2004. Determinants of customer loyalty and financial performance. Journal of Management Accounting Research 16: 183-205. [CrossRef]

Sprott, David, Sandor Czellar, and Eric Spangenberg. 2009. The importance of a general measure of brand engagement on market behavior: Development and validation of a scale. Journal of Marketing Research 46: 92-104. [CrossRef]

Teng, Ching-I. 2018. Managing gamer relationships to enhance online gamer loyalty: The perspectives of social capital theory and self-perception theory. Computers in Human Behavior 79: 59-67. [CrossRef]

Torres, Anna, and Josep A. Tribó. 2011. Customer satisfaction and brand equity. Journal of Business Research 64: 1089-96. [CrossRef]

Tranfield, David, David Denyer, and Palminder Smart. 2003. Towards a methodology for developing evidence-informed management knowledge by means of systematic review. British Journal of Management 14: 207-22. [CrossRef]

Tsai, Hsien-Tung, and Heng-Chiang Huang. 2007. Determinants of e-repurchase intentions: An integrative model of quadruple retention drivers. Information \& Management 44: 231-39.

$\mathrm{Tu}, \mathrm{Yu}-\mathrm{Te}$, Chin-Mei Wang, and Hsiao-Chien Chang. 2012. Corporate brand image and customer satisfaction on loyalty: An empirical study of Starbucks coffee in Taiwan. J. Soc. Dev. Sci. 3: 24-32.

Van Doorn, Jenny, Katherine N. Lemon, Vikas Mittal, Stephan Nass, Doreén Pick, Peter Pirner, and Peter C. Verhoef. 2010. Customer Engagement Behavior: Theoretical Foundations and Research Directions. Journal of Service Research 13: 253-66. [CrossRef]

Vargo, Stephen L., and Robert F. Lusch. 2004. Evolving to a new dominant logic. Journal of Marketing 68: 1-17. [CrossRef] 
Vargo, Stephen L., and Robert F. Lusch. 2008. Service-Dominant Logic: Continuing the Evolution. Journal of the Academy of Marketing Science 36: 1-10. [CrossRef]

Verhoef, Peter C., Werner J. Reinartz, and Manfred Krafft. 2010. Customer Engagement as a New Perspective in Customer Management. Journal of Service Research 13: 247-52. [CrossRef]

Villanueva, Julian, Pradeep Bhardwaj, Sridhar Balasubramanian, and Yuxin Chen. 2007. Customer relationship management in competitive environments: The positive implications of a short-term focus. Quantitative Marketing and Economics 5: 99-129. [CrossRef]

Vivek, Shiri D., Sharon E. Beatty, and Robert M. Morgan. 2012. Consumer engagement: Exploring customer relationships beyond purchase. Marketing Theory and Practice 20: 122-46. [CrossRef]

Waltman, Ludo. 2016. A review of the literature on citation impact indicators. Journal of Informetrics 109: 365-91. [CrossRef]

Wathne, Kenneth H., Harald Biong, and Jan B. Heide. 2001. Choice of supplier in embedded markets: Relationship and marketing program effects. Journal of Marketing 65: 54-66. [CrossRef]

Wirtz, Jochen, Anouk Den Ambtman, Josée Bloemer, Csilla Horváth, Balasubramanian Ramaseshan, Joris Van De Klundert, Zeynep Gurhan Canli, and Jay Kandampully. 2013. Managing brands and customer engagement in online brand communities. Journal of Service Management 24: 223-44. [CrossRef]

Wu, Ya-Ling, and Eldon Y. Li. 2018. Marketing mix, customer value, and customer loyalty in social commerce: A stimulus-organism-response perspective. Internet Research 28: 74-104. [CrossRef]

$\mathrm{Xu}$, Jing, and Andrew Chan. 2010. A conceptual framework of hotel experience and customer based brand equity: Some research questions and implications. International Journal of Contemporary Hospitality Management 22: 174-93.

Yadav, Manjit S., Kristine De Valck, Thorsten Hennig-Thurau, Donna L. Hoffman, and Martin Spann. 2013. Social commerce: A contingency framework for assessing marketing potential. Journal of Interactive Marketing 27: 311-23. [CrossRef]

Yi, Youjae, and Hoseong Jeon. 2003. Effects of loyalty programs on value perception, program loyalty, and brand loyalty. Journal of the Academy of Marketing Science 31: 229-40. [CrossRef]

Yi, Youjae, and Suna La. 2004. What influences the relationship between customer satisfaction and repurchase intention? Investigating the effects of adjusted expectations and customer loyalty. Psychology $\mathcal{E}$ Marketing 21: 351-73.

Yoshida, Masayuki, Brian S. Gordon, Makoto Nakazawa, Shigeki Shibuya, and Naoyuki Fujiwara. 2018. Bridging the gap between social media and behavioral brand loyalty. Electronic Commerce Research and Applications 28: 208-18. [CrossRef]

Zhang, Mingli, and Nuan Luo. 2016. Understanding relationship benefits from harmonious brand community on social media. Internet Research 26: 809-26. [CrossRef]

Zhang, Sha Sandy, Jenny van Doorn, and Peter S. H. Leeflang. 2014. Does the importance of value, brand and relationship equity for customer loyalty differ between Eastern and Western cultures? International Business Review 23: 284-92. [CrossRef]

Zhou, Zhimin, Qiyuan Zhang, Chenting Su, and Nan Zhou. 2012. How do brand communities generate brand relationships? Intermediate mechanisms. Journal of Business Research 65: 890-95. [CrossRef]

Zins, Andreas H. 2001. Relative attitudes and commitment in customer loyalty models: Some experiences in the commercial airline industry. International Journal of Service Industry Management 12: 269-94. [CrossRef]

Zupic, Ivan, and Tomaž Čater. 2015. Bibliometric methods in management and organization. Organizational Research Methods 18: 429-72. [CrossRef]

(C) 2019 by the authors. Licensee MDPI, Basel, Switzerland. This article is an open access article distributed under the terms and conditions of the Creative Commons Attribution (CC BY) license (http://creativecommons.org/licenses/by/4.0/). 